\title{
The Creation Form and Aesthetic Characteristics of the Art Works of the Great Northern Wilderness Under the Historical Background*
}

\author{
Guo Yang \\ Heihe University \\ Heihe, China
}

\begin{abstract}
The art of the Great Northern Wilderness was produced under the background of special times and it was inevitably influenced by the times deeply. Starting from this, the paper begins with an overview of the background of the birth and development of the Great Northern Wilderness art followed by analyzing the creative forms of the art works from the perspectives of prints, oil paintings, Chinese paintings and propaganda paintings. Finally, the aesthetic characteristics of this special art are induced and summarized, which are concluded as three aspects: the content of life, the creative techniques of imagery, and the creative style of diversification.
\end{abstract}

Keywords-the Great Northern Wilderness art; creative form; aesthetic characteristics

\section{INTRODUCTION}

The Great Northern Wilderness is located in Heilongjiang Province in the northern border of China, accounting for about a quarter of the province's area. Situated at the junction of Songhua River, Wusuli River and Heilongjiang River Basin, the Great Northern Wilderness enjoys fertile lands and vast territory. In the early days of the wilds, there were few people, but just a boundless stretch of wastelands, swamps, mountain forests, and snow and ice. "There is no one to live within a hundred of miles in the square, and the wilderness is boundless." is the authentic portrayal of the Great Northern Wilderness. After the founding of the People's Republic of China, the strategic significance of this place has become increasingly prominent. So, since the mid-1950s, a large number of soldiers and intellectual youths were ordered to the Great Northern Wilderness to reclaim and defend the frontier, making the Great Northern Wilderness an important food base for China and also winning the reputation of "Northern Granary". Then, plenty of people have flowed into the area, which has also spawned the featured Northern Great Wilderness literature, of which the Northern Wilderness art was an excellent representative. The educated youth was the main creator of this unique art, beginning in the 1950s. Until today, the Northern Wilderness art is still an important representative of Chinese contemporary art.

*This paper is a phased achievement of the 2017 Heilongiiang Provincial Philosophy and Social Science Research Project "Art Research of the Great Northern Wilderness Educated Youth", and its project number is: 17YSE389.

\section{THE HistORICAL BACKGROUND OF THE CREATION OF GREAT NORTHERN WILDERNESS ART WORKS}

The art of the Northern Wilderness differentiates itself in narrow and broad sense. In the narrow sense, the art refers to the works of reclamation period in the Great Northern Wilderness and the period of the Cultural Revolution. The art in the broad sense covers the works from the 1950s to the end of the Cultural Revolution. The art of the Northern Wilderness are mainly produced by the educated youth with the theme of production and life as well as the natural scenery in the Great Northern Wilderness. The birth and development of the Great Northern Wilderness art is inseparable from the era. In the 1950 s, the country began to organize the development of the Great Northern Wilderness. In 1958, with the advent of extensive exploitation, there were lots of other educated youths, as well as revolutionary cadres and soldiers coming to the Great Northern Wilderness. In response, this was the first time that the Northern Wilderness art flourished. In the middle of the Cultural Revolution, in response to Chairman Mao's call to go to the countryside, many urban youths came to the Great Northern Wilderness, forming the second great prosperity of the art creation of the Northern Wilderness. After the Cultural Revolution, although artists returned to the city in succession, the years of educated youth were still an important theme of their art creation. What's more, influenced by the shifts of the times climate, there has been a change in art technique and style.

\section{THE MAIN CREATION FORM OF THE NORTHERN WILDERNESS ART WORKS}

\section{A. Print}

Printmaking is the most famous and influential creation form in the Great Northern Wilderness. It first appeared in the great reclamation period of the 1950s. According to its development context, it can be divided into early stage, middle stage and late stage. During the periods, from 1958 to 1968 , the early period and from 1968 to 1978 , the mid-term period, the art creation stepped into peak prosperity and the classic prints ranked top in the number. The number of prints in the Northern Wilderness art is mostly in the form of chromatically mimeographed wooden prints with important breakthroughs in many fields. First of all, in terms of color, the Great Northern Wilderness prints change the color representation of traditional 
prints in black and white, and use more other colors as the modeling method, which greatly enhances the artistic expression of prints. Secondly, in terms of size, the Great Northern Wilderness prints are usually large in measurement with the laminated plywood as carrier. The works of thousands of square centimeters can often be seen. And they tend to be strong visual impacts on the content presentation, making them especially suitable for the performance of major historical subjects and panoramic views of life. The prints of the Great Northern Wilderness are endowed with the artistic characteristics of roughness and realism of Longjiang art. In early creation period, there are many famous printmakers, and most of them are professional artists. Lives in the Northern Great Wildness offered them new creative enthusiasm and inspiration. Among the artists, the most prestigious one is the Chao Mei. In 1958, he came to the Great Northern Wilderness with soldiers, and worked in the fifth branch, which was the remotest branch of 853 Farm and had the extremely bad natural environment. The unique life experience was recorded in the form of prints by Chao Mei, that was, "First Footprint". Beyond the expression of life experience of Chao Mei himself, the works conveys a reality that the educated youth sacrifice themselves to the borderland construction of the motherland. Zhang Zuoliang's "Walking on Ice" and Zhang Zhenlin's "Reture from Pasture" are also the representative prints of this period.

\section{B. Oil Painting}

The educated youth art with oil painting as its original style was first born in the mid-1950s, and the Great Northern Wilderness was one of the most important bases for educated youth oil painting. Although the first batch of educated youth was not many, they played a very important role in the practice of the Northern Wilderness Art. A large number of classic oil paintings with the theme of the reclamation in Great Northern Wilderness were created in this period. There was a relatively important works named "Qijia", which was created by Zhan Jianjun in 1957. This is a thematic painting depicting the work scenes of the first batch of young voluntary reclamation team in the Great Northern Wilderness. The works are presented with the background of pre-storm and shows a scene of team members camping in the difficult working environment. The spirit of conquering nature shown in the picture and the theme of transforming the Great Northern Wilderness stand for the belief and pursuit of the reclamation team. The oil painting creation in this period was deeply influenced by the Soviet oil painting in the technique. At that time, the two Parties and the two countries were in the most closely related period in history, and they shared the responsibility of resisting the Western World. Therefore, it is inevitable that the Soviet Union would be the master of Chinese painting techniques. During the Cultural Revolution, the construction of the Great Northern Wilderness begun to bear fruit, and the Great Northern Wilderness has been gradually becoming the Northern Granary, stimulating the theme change of creation naturally. For example, Zhao Xiaomo's "Luxuriant Earth", created in 1972 shows the joy of the people in harvest season. After the end of the decade of Cultural Revolution, a large number of young people returned to the cities from the Great Northern Wilderness, and the style of oil painting undergone tremendous changes. Especially with the increasing openness of the country's literary and artistic creation policies, oil paintings that were completely different from those of the Reclamation period and the Cultural Revolution period coming out in large numbers, Art of Scars and Reflective Art occupied the main body of oil painting creation in this period. The dark and gloomy style of the painting replaced sunny temper in the early and middle stages and the realistic and humanitarian oil paintings got popular.

\section{Chinese Painting}

Compared with prints and oil paintings, Chinese paintings are a form of "small crowd" in the art of the Northern Wilderness. It is difficult for both the painter group and the creative works to compete with the above two forms. Although Chinese painting does not occupy an advantage in quantity, it has distinct characteristics in terms of content and form innovation. Ink and wash painting is the representative of Chinese painting with the combination of water and ink as the carrier and landscapes, flowers and birds, still life, customs as common themes. The ink paintings in the Northern Wilderness Art are mostly in the number of figure paintings, especially the shaping and presentation of the image of workers, peasants and soldiers, carrying a strong political hue. From the 1950s to the end of the Cultural Revolution, everything that was not related to politics was abandoned in the creation of Chinese painting. The characters in Chinese painting also showed distinct characteristics of the times. These paintings focused on the spiritual state by mainly portraying figures of combat, idealization and exaggeration. In the composition of Chinese painting, "three prominent principle" were also very obvious. The main positive person tends to be the center of the figure painting, and the composition was carried out based on this principle. During this period, the representative writer of the Northern Wilderness Chinese painting was Hou Guoliang, who went to the Great Northern Wilderness in 1968 and transferred to the Harbin Painting Institute in 1979. He spent 11 years in the Great Northern Wilderness, during which he created many representative Chinese paintings. The famous one was "They Grew up in the Borderland" $(1500 \mathrm{~cm} \times 900 \mathrm{~cm})$, which was finished in 1972. The painting is based on the woodland of the Great Northern Wilderness in winter, showing the highspirited attitude of the educated youth. The faces of the central figures are filled with labor smiles, consistent with the style of painting in that specific period.

\section{Propaganda Painting}

Whether it is print, oil painting, or Chinese painting, it is classified based on creative means, or creation medium, but picture poster is different. It is defined based on the theme of creation. Therefore, it is not parallel to the former three creations in style, but holds the relationship with them of "you are among us and we are among you". In fact, there are not a few propaganda works in prints, oil paintings, and Chinese paintings. Most of the art works in the early and middle stages of the Northern Wilderness have a distinctive propaganda style, which is an inevitable expression of the literary servicing politics. After the reform and opening up, with the diversification of creative ideas and the liberalization of the literary and artistic creation atmosphere, the proportion of picture posters in the art works of Great Northern Wilderness were gradually reduced, and the paintings based on the 
individual emotions of the painters came out. According to the different propaganda objects, the picture posters in the art works of the Great Northern Wilderness can be divided into two major categories. The first category takes the characters as the main body with the depiction and shaping of hero characters, showing the positive figures that meet the requirements of the times and have a propaganda role. The second type is the posters with the main theme of the event. They closely follow the policies of the Party and the state and the major events in social and political life. By means of the form of painting, the effect of propaganda will be realized. One of the pretty typical ones is Liu Yulian's "We Are Glorious Corps Soldiers", which is an art work of 1972 with the soldiers of the Corps as a propaganda object, conveying the spirit of them in the era of revolutionary construction. Although the painting is featured by group figures, the image of female educated youth in the upper left corner is particularly prominent. The full mental state and high revolutionary enthusiasm have a good publicity effect.

\section{AESTHETIC CHARACTERISTICS OF THE GREAT} NORTHERN WILDERNESS'S FINE ARTS CREATION UNDER THE HISTORICAL BACKGROUND

\section{A. Content of Life}

Art creation requires both wild imagination and down-toearth observations. Only in this way can the imagination be authentic and infective. Just as the famous writer Hugo said, "The artist's feet must not have no soil." Life is the source of artist creation. Unexceptionally, the important position of the Great Northern Wilderness Art in contemporary art is closely related to the meticulous observation and profound expression of life by the painter community. The works of the Great Northern Wilderness art have distinct characteristics of life in their creations with the main areas of life as following: first, production and life. Due to the sparse population in the early stage of the Great Northern Wilderness, despite the abundant natural resources, the grain output was extremely low and the land was deserted. The first batch of educated youths shouldered the heavy responsibility of opening up the wasteland for farming and production work was their most important task. Therefore, the theme of the paintings was mostly based on the scene of production activities, showing the vigorous labor energy of the revolutionary construction era and the patriotic feelings of building the motherland. From Ge Weimo's "To the Place Where the Motherland Needs most" to Zhan Jianjun's "Qijia", all of works focused on labor production; secondly, military life. The educated youth going to the countryside tend to be the peasants in the agricultural areas or the soldiers in Production and Construction Corps. Most of the Great Northern Wilderness educated youth were affiliated with the Heilongjiang Production and Construction Corps and had the status of armyman, which hadn't been cancelled until 1976 when the state farm was established. Therefore, military life has become an important performance theme of the Great Northern Wilderness art. Many art works were based on the theme of sentry, such as Shen Jiawei's "On the Sentry Duty for Our Great Motherland"; finally, daily life. Before the Cultural Revolution, the art of the Great Northern Wilderness was influenced by the atmosphere of the times and had a strong political hue. However, there were also a number of works that expressed the delicate emotions of people in daily life in the environment. These works are good at showing the joys and sorrows of educated youth from the details. For example, Wang Chengyi's "Home Letter" depicts that the female educated youth is immersed in the joyful and happy reading after getting a letter from a distant hometown. And the whole picture carries soothing atmosphere and sincere emotion.

\section{B. Creative Techniques of Imagery}

In the early days, the creation of the Northern Wilderness Art was mainly based on the presentation of life scenes. However, with the increasing enrichment of creative practice, the imagery creation method gradually became the mainstream. The painter presented the natural environment of the Great Northern Wilderness with a unique image, and shaped the hero character images in special environment. The imagery creation method has terse and concise style with simple words and profound artistic conception. And it helps to express the artists' creative ideas and appeals with great imagery. One of the most common images in the early and mid-stage art works of the Great Northern Wilderness is the soldiers, especially the female soldiers. Chairman Mao has poetry saying that "the Chinese women are so lofty in their ideals, they do not love the red dress but love the armed forces", so, the female soldiers have become the spokesmen of women's production and construction as well as defending the country in the certain era. Snowfield is one of the most frequently appearing images in the art of the Great Northern Wilderness. The Great Northern Wilderness is located in the northern edge of the country, so that the natural environment there is extremely harsh and the winter climate is so cold. Accordingly, the snow is the most compact and most effective carrier for the natural environment. Many painters have snow images in their works, such as Chao Mei's "First Footprint". Du Hongnian participated in the reclamation cause of the Great Northern Wilderness in 1958. $\mathrm{He}$ was one of the first intellectual youths to reach the Great Northern Wilderness and was also one of the pioneers of the prints of the Great Northern Wilderness. His prints are mostly based on snow, such as the "Great Wall of Northern Borderland", "The Songs on the Way Home from Sending Meals", and "Spring of the North" and so on.

\section{Creative Style of Diversification}

The art works of Great Northern Wilderness began in the mid-1950s, flourished in the Cultural Revolution, and transformed after the reform and opening up, so that it is diversified in creative style, which is mainly manifested in two points. First, there are different dominant styles in different periods. The creation process of Great Northern Wilderness art is long and can be divided into several different stages, such as the pre-Cultural Revolution period, the Cultural Revolution period, the late Cultural Revolution period, and the reproduction period. The styles of each stage are very different, for example, in the art of the pre-Cultural Revolution and the Cultural Revolution, most of the works were romantic full of enthusiasm for revolutionary construction, and the art works after the end of the Cultural Revolution changed the style of painting, and the reflective works of realism gradually occupied the mainstream; secondly, the style of art works in the same period is also not small in difference. Influenced by the individual disparities of the painters, there would be some 
distinctions in the style of the works of art in the same period. Even during the Cultural Revolution, when political propaganda works dominated the mainstream, there were still some other styles of works. For example, the "Home Letter" against the background of the Great Reclamation of the 1950s is a work characterized by faintness and soothing, which is different from the mainstream style. Among them, the works of Hao Boyi is the most special. Hao Boyi was transferred to the civilian work and went to the Great Northern Wilderness in 1958. He created a large number of masterpieces that preserved both Chinese ink and water charm and the rich colors of mimeographed prints. Natural scenery is his main creative content, showing a style of art that is free from the times.

\section{CONCLUSION}

The period from the 1950 s to the reform and opening up was very extraordinary in China's construction and development, and the transformation of the Great Northern Wilderness was the epitome of this period. During the times, a large number of educated youths went to the Great Northern Wilderness to engage in land reclamation and construction, turning the barren Great Northern Wilderness into China's "Northern Granary", which also gave birth to the development and prosperity of the Great Northern Wilderness literature and art. In the history of art in New China, the art of the Northern Wilderness has a very special status with great contribution of a large number of classic art works to China both in creation form and aesthetic characteristics.

\section{REFERENCES}

[1] The Document Editing Committee of 30 Years of the Great Northern Wilderness Prints. The 30th Anniversary of the Great Northern Wilderness Prints [M]. Harbin: Heilongjiang Fine Arts Publishing House, 1988

[2] Yang Guo. Research on the Art of Educated Youth in the Great Northern Wilderness[J]. Beauty and the Times (Middle), 2017(01): 5960

[3] Wang Hongbo. Analysis of the Origin of Prints in the Great Northern Wilderness[J].Art Research, 2008(03):139-140

[4] Zeng Xisheng. The Trilogy of Youth Narration - The Historical Evolution of Chinese Educated Youth Oil Painting[J]. Journal of Nanjing Art Institute (Fine Arts \& Design), 2010 (6):51-57

[5] Tan Tian, Wu Shuang. Reflections on the Integrity of New China's Fine Arts Research - Taking the Study of "Educated Youth Art" as an Example[J]. Hubei Institute of fine Arts Journal, 2011(02):55-56

[6] Wang Zhankun. Research on the Characteristics of the Artistic Creation of the Educated Youth in the Great Northern Wilderness[J]. Art and Design, 2014(12): 129-131

[7] Lv Dandan. Research on the Theme and Expression Forms of the Educated Youth Prints in the Great Northern Wilderness during the Cultural Revolution [J]. Economic Management Journal , 2016 (07): 85 